\title{
オフィス照明の満足度に及ぼす明るさの個別調節の効果
}

\author{
正会員宮澤縫衣子 尃門会員 中 村 芳 樹 正会員 若 狭 直 毅（東京工業大学大学院）
}

\section{Effect of Personal Control of Illumination on Satisfaction of Office Lighting}

Member Nuiko Miyasawa (Tokyo Institute of Technology),

Fellow Member Yoshiki Nakamura (Tokyo Institute of Technology) and

Member Naoki Wakasa (Tokyo Instltute of Technology)

\begin{abstract}
To clarify importance of personal adjustments with office lighting, authors interviewed 17 general office workers and 38 experts in lighting industry. We also conducted the experiments to quantify the effect that having the ability to change the illumination level themselves had on the workers' satisfaction and to distinguish between the effect resulting from "Control" and one from the change itself.

The interviews showed that both the general office workers and the lighting designers perceived lighting adjustments as a key factor, while importance of the adjustment was not recognized so much. The experiments showed that evaluations of the luminous environment differed greatly depending on whether the evaluator was able to adjust the lighting level, while both the effect resulting from "Control" and one from the change in illumination level were slight.
\end{abstract}

KEYWORDS : control, change in illumination level, office lighting, satisfaction, interview, evaluation

\section{1.はじめに}

空調や照明などの個別調節化は, 多様化した個々人の欲求を満 たし快適性を上げると共に，作業性や知的な生座性の向上につな がると考えられており, 近年重要視されつつある建築空間の快適 性を考える上で, 考虑すべき重要な要因の一つになってきている. またうまく設計すれば，省エネルギーとの両立も四ることができ る*. 今後どのような形で個別調節化を進めていくかということ は，室内環境を考之る際にも大きな影響を与えることは間違いな いだろう。

照明の分野においての個別調節には，例えば自分で行う明るさ の調節が挙げられる。しかし今までの照明設計において自分で行 う明るさ調節は主要な検討項目であったとは言い切れず，そのた め現在人々がどのような価值を明るさ調節に見い出しているかは 明らかでない。そこで本研究では明るさ調節の効果を定量的に検 討古ることを試みる。

\section{2. 既往研究の検討}

明るさ調節を対象とした研究はこれまでに見られないが，明る さの調節に関連して, Veitch $(1996)^{1}{ }^{1}$ は，机上面が同照度で各照 明器具の出力が異なる 3 種類のタスクアンビエント比から 1 つを

本論文の一部は、平成11年度照明学全全国大会で宮澤縫衣子が講演した

* 例えば「インテリジェントビルの視環境と照明」特集,照明学会誌Vol.71，1987年 11 月で，タスク・アンビエント照明方式を採用した設計例が紹介されている.
選択寸る効果を, controlの概念を用いて検討した。

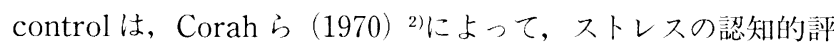
価を決定する要因引3月11 と定義されている。英語の「control」は， 一般に「統制」や「支配」と翻訳されるが，ここでの control はそ のような意味ではなく，ある環境（ここではストレス）の評価に 影響を与える要因として捉えられている。一方，Averill (1973) ${ }^{3)}$ は, control がストレス (悪環境)を評価する時に影響を与えると 考え, control とストレスに対処する状態の関係を詳細に検討し た。そして，環境への直接的な行動引用2 を『behavioral control』 と呼び，さらに，ある事柄がどのように生起卞るかを認知してい る状態にも又 control があるとして，それを『cognitive control』 と呼んだ。そしてさまざまな選択肢の中から敢えて悪い方を選び それをポジティブに捉える場合も controlがあるとし，これを 『decisional control』と呼んだ. Averill は control をこれら $3 つ$ の側面から捕らえる必要性を指摘した。また Barnes (1981) $)^{4}$ は, cognitive controlのある状態うち，特にその事柄を生起する原因 が自分にあり，自分の選択が結果を決定すること引用3，つまり自分 がストレスに対して何かできると知っていることでストレスに対 処できる状態を『perceived control』がある状態と呼んだ.

これらをうけて宮澤ら $(2000)^{4)}$ は, 被験者に実際にオフィス照 明の明るさの調節をさせ, controlの効果の存在の確認を行った。 しかしこの研究では，オフィス照明の中での調節の位置付けが不 明確で，また具体的に controlの効果の定量的検討が行われてお らず十分とは言い切れない。 


\begin{tabular}{|c|c|c|c|c|}
\hline 段階 & 被験者に問う事柄 & \multicolumn{2}{|c|}{ 目的 } & 被験者への提示 \\
\hline$\langle 1\rangle$ & オフィス照明の要件 & \multicolumn{2}{|r|}{ 普段から意識しているオフィス照明の要件を探る } & \multirow{5}{*}{ 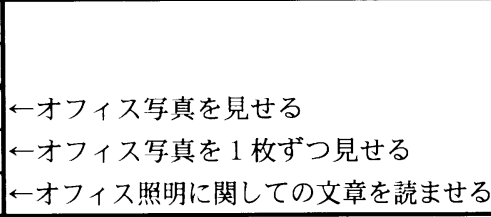 } \\
\hline$\langle 2\rangle$ & オフィス照明の分類方法 & \multicolumn{2}{|r|}{ 普段から意識しているオフィス照明を分類視点を探る } & \\
\hline$\overline{\langle 3\rangle}$ & オフィス照明の分類方法 & \multirow{3}{*}{$\begin{array}{l}\downarrow \\
\downarrow \\
\downarrow\end{array}$} & 写真を見せることで喚起する & \\
\hline$\langle 4\rangle$ & オフィス写真の説明 & & 写真を細部に渡り見せることで更に喚起する & \\
\hline$\overline{\langle 5\rangle}$ & オフィス照明の分類方法 & & 教科書的な知識を与えることで更に喚起する & \\
\hline
\end{tabular}

\section{3. 本研究の目的}

本研究では，はじめに人々が日常的に体験している時間が長い と思われるオフィスを取り上げ，オフィスの執務者がオフィス照 明をどのように捉えているかを把握し，その中での調節の位置付 けを明確にする。次にこれをふまえ, 被験者に実際にオフィス照 明の明るさを調節させ，明るさ調節の効果を定量的に明らかにす ることを目的とする。

また本研究では, 自分で行なう明るさ調節のみを扱い, 『明るさ 調節』を「快適な環境を作るために明るさを変化させること」，そ して『control』を「調節に伴って定常状態との評価の差を生み出 す要因」と定義し, 明るさ調節を以下に示すような controlの概念 を用いて記述する。

(1) behavioral control

自分が良くした環境の評価と，その環境が単独で与.えられた時 との評価の差を生み出した要因

例）暗いのでスイッチを押して明るくした環境の評优と，その環 境が単独で与えられた時との評価の差を生み出した要因

(2) decisional control

自分が敢えて悪くした環境の評価と, それが単独で与えられた ときとの評価の差を生み出した要因

例）省エネのために敢えて照明を消した環境の評価と，その環境 が単独でちえられた時との評価の差を生み出した要因

(3) perceived control

必要であれば自分が環境を調節できるという認知を持つこと で，その環境が単独で与えられた時との評価の差を生み出守要因 例）現在は暗いけれども，必要であればいつでも自分で照明を点 けて明るくできると知っている時と，それを知らない時との評価 の差を生み出す荘因

そして「 controlなし」とは，上記のような要因が全くない状態 である。本研究ではこれらの controlのうち behavioral control と perceived controlの効果を定量的に検討することを目的と古 る。また decisional controlに関してはその頻度は behavioral controlに比べて少なく, 個人の価值観が影響导るので, 本研究で は検討しない.

\section{4.オフィス照明における個別調節の位置付けのための 面接実験}

\section{1 実験の概要}

被験者個人が持つオフィス照明を評価する上での検討項目とそ の捉え方を抽出し，それら検討項目の中での調節の位置付けを明 確にするための面接実験を行った。

実験は 5 段階で構成され，各個人に対して面接形式で行われた (表 1 ). 被験者には，オフィス照明環境評価に相違が見られると
思われる属性として，照明デザイナ一，照明エンジニア，照明に 対して専門知識を持たない人の 3 属性を定め，それぞれ 21 人， 17 人，17人の計 55 人を選定した。 以下，被験者の属する各属性をそ れぞれ，「デザイナー」「エンジニア」「一般オフィスワーカー」と 寸る。被験者はいずれも普段オフィスで働くオフィス執務者とし た. 表 2 に被験者の構成を示玄.

\section{2 実験手順一評価軸の抽出一}

予備実験を行った結果，被験者から得られる分類䐜目は「十分 明るい」といった文章で表現されることが多いことが分かったが， この言葉には「明るい」という視点に「十分」という評価が加わ っている。 そのため，これらの分類項目から「どのようか」とい う評価を分離させ,オフィス照明の捉えかたの視点のみを抽出し, 表現を統一することにした。

被験者が言及した言葉が何を意図しているかはその対立概念を 聞くことでより鮮明になると考えられる。 そこで次にこの対立概 念在聞き出すために，例えば「明るい」と被験者が挙げた時には， オフィス照明の分類として，「明るい」の対になる言葉があるかど うか，あればその分類もあるかどうかを聞き，被験者から「そう です」という回答が得られた場合，オフィス照明の視点を，两極 を持つような『軸』の形式で抽出した.

子備実験において, 評価軸には「明るい一暗い」のように段階 的評価がされるもの，「空の大きさ」のように段階的または ON$\mathrm{OFF}$ 的にも評価されるもの，また「口の字・ペンダント」のよう に両極を持なない尺度として評価されグループに分類されるもの があった。そしてこれらの評価には，グレアのあるなしのように どちらかがいいもの，明るい一暗いのように適值があるもの，空 の有る無しのように被験者によって適值があると判断されたりど ちらか一力が良いとされるもの，半間接照明のように一概に良し 悪しが言えないものがあった。そこで次の段階として，このよj な要件や分類方法の尺度特性とその評価の関係を明らかにするこ とにした(図 1 ).

そして被験者に要件や分類方法がオフィス照明を判断する上で どの程度重要かを「必要不叮欠なくらい重要」「かなり重要」「子 つうに重要」「あればいい」の４段階で評価させた。

表 2 被験者の構成

Table 2 The data of the subjects.

\begin{tabular}{|c|c|c|c|c|}
\hline & デザイナー & エンジニア & 段オフイスワーカー \\
\hline \multirow{2}{*}{ 20代 } & 男 & 2 & 3 & 2 \\
\hline & 女 & 3 & 2 & 10 \\
\hline \multirow{2}{*}{ 30代 } & 男 & 12 & 7 & 2 \\
\hline & 女 & 3 & 3 & 0 \\
\hline \multirow{2}{*}{ 40代 } & 男 & 1 & 2 & 1 \\
\hline & 女 & 0 & 0 & 0 \\
\hline \multirow{2}{*}{ 50代 } & 男 & 0 & 0 & 2 \\
\hline & 女 & 0 & 0 & 0 \\
\hline 合言 & & 21人 & 17人 & 17人 \\
\hline
\end{tabular}




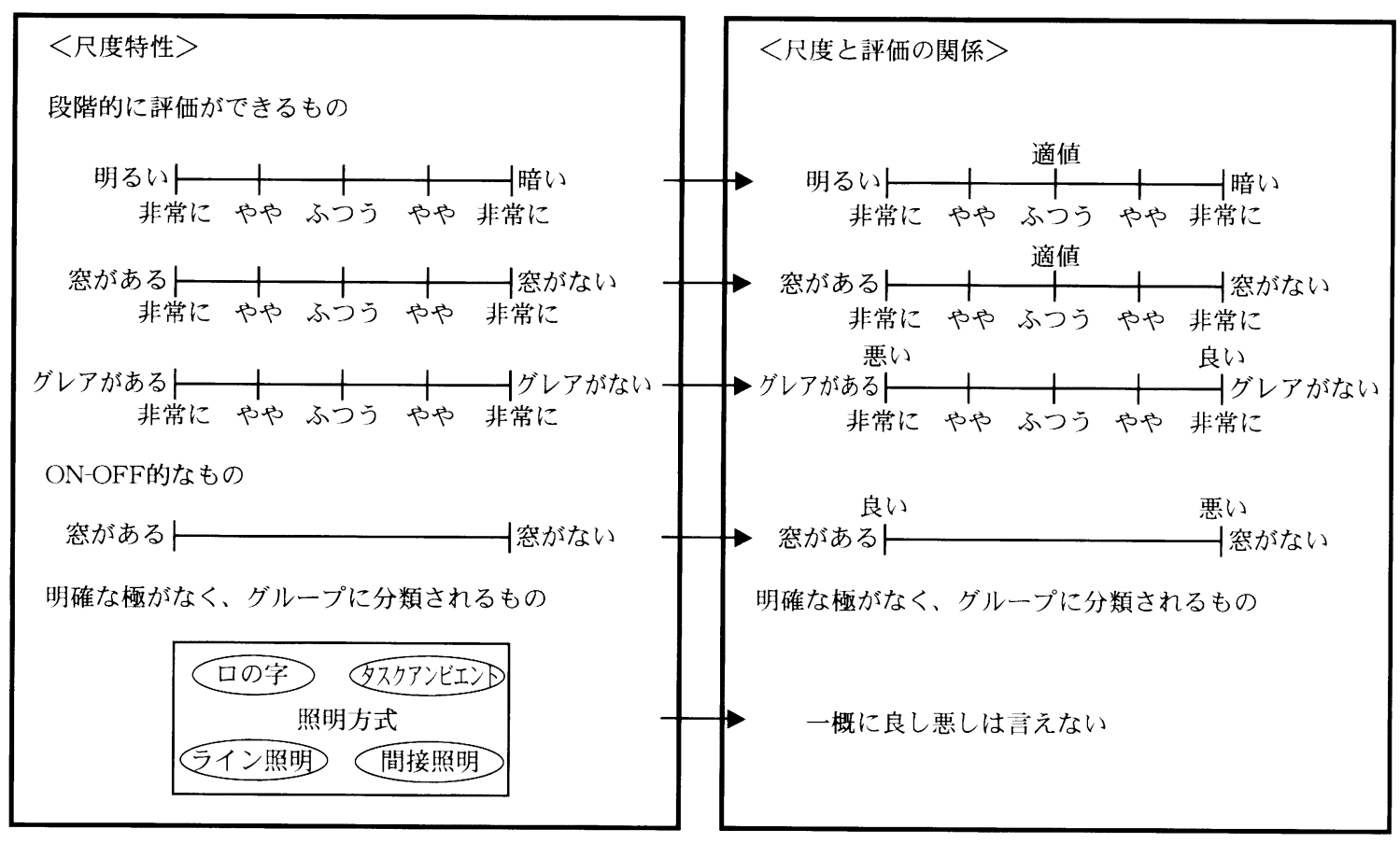

目 1 要件や分類方法の尺度特性とその評価との関係

Fig. 1 The feature of the scales of requirement \& classification and rerationship of it \& evaliation.

表 3 79項目の細分類視点（黒はカテゴリー）

Table 379 small view points (Black ones are categories).

\begin{tabular}{|c|c|c|c|}
\hline 1明るさ & 21 器具自体の様相 & 41 少工社 & 61 任 \\
\hline 2 周辺の明るさ & 22 建築化照明 & $\begin{array}{ll}42 & \text { 照明制御 } \\
\end{array}$ & 62 内装の色 \\
\hline 3 天井の明るさ & \begin{tabular}{|l|l|}
23 & 間接照明 \\
\end{tabular} & \begin{tabular}{l|l}
43 & 昼光利用 \\
\end{tabular} & \begin{tabular}{l|l|l|}
63 & インテリアの色 \\
\end{tabular} \\
\hline \begin{tabular}{l|l}
4 & 壁の明るさ \\
\end{tabular} & \begin{tabular}{l|l}
24 & 照明方式 \\
\end{tabular} & 44 時系列 & 64 炎の方向性: \\
\hline \begin{tabular}{|l|l|}
5 & 夜の明るさ \\
\end{tabular} & \begin{tabular}{l|l}
25 & 天井照明 \\
\end{tabular} & 45 センサー & \begin{tabular}{l|l|l|}
65 & モデリング \\
\end{tabular} \\
\hline \begin{tabular}{l|l|}
6 & 手元の明るさ \\
\end{tabular} & \begin{tabular}{l|l|}
26 & 天井の高さとの関倸 \\
\end{tabular} & 46 ゾーニング & \begin{tabular}{l|l}
66 鈆直面照度 \\
\end{tabular} \\
\hline \begin{tabular}{l|l}
7 & 全体の明るさ \\
\end{tabular} & 27管の露出状態 & 47 直射光 & 67 グレア \\
\hline 8 均斉度 & 28 ペンダント & 48 白然光阅係 & \begin{tabular}{l|l|l|l|l|l}
68 & グレ制御・G分類 \\
\end{tabular} \\
\hline 9 机上の関係 & $\begin{array}{l}29 \text { 器具の数 } \\
\end{array}$ & 49 ブラインド & 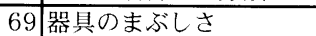 \\
\hline \begin{tabular}{|l|l|}
10 & 配置換えに対応 \\
\end{tabular} & 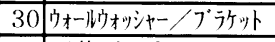 & 50 空 / 採光 & \begin{tabular}{l|l}
70 まぶしさ \\
\end{tabular} \\
\hline 11 机と照明のレ仍外 & \begin{tabular}{l|l}
31 & 天井面がすっきり \\
\end{tabular} & 51 眺望 & 71 ルーバー \\
\hline 12 配光 & 32 パーティション & 52 急激な明るさの変動 & 72 映り込み \\
\hline 13 尽伩心照明 & $33 \mid$ トップライト & 53 開放感 & \begin{tabular}{l|l}
73 & グレア光源 \\
\end{tabular} \\
\hline 14 外からの見え & 34 洞箱隹 & 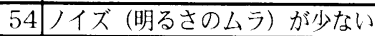 & \begin{tabular}{l|l}
74 & 反射 \\
\end{tabular} \\
\hline 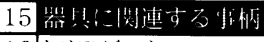 & \begin{tabular}{l|l|l}
35 & 目的ごとの調節 \\
\end{tabular} & 55 霖团父 & \begin{tabular}{l|l}
75 & 背景輝度 \\
\end{tabular} \\
\hline 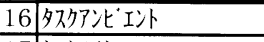 & 36 部屋全体の調節 & \begin{tabular}{l|l|}
56 & リラックス \\
\end{tabular} & 76 必要照度を満たしている \\
\hline \begin{tabular}{l|l|}
17 & 欢ライト \\
\end{tabular} & 37 光源 & 57 疲れ & \begin{tabular}{l|l}
77 & 照明の組み合わせ \\
\end{tabular} \\
\hline 18 夘仆の有効利用 & 38 色温度 & \begin{tabular}{l|l}
58 & 活気・楽しさ \\
\end{tabular} & $\begin{array}{l}78 \\
\text { 照明手法 } \\
\end{array}$ \\
\hline 19 間接照明の効率 & 39 演色性 & 59 デザイン & 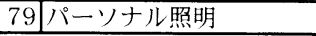 \\
\hline 20 局所と全般 & 40 50 ちらつき & 60 60 コーナー分け & \\
\hline
\end{tabular}

最後に，尺度特性が明らかになった評価軸やグループ分類の上 に被験者間でどの程度その捉えかたに整合性があるかを明らかに するために，19枚のオフィス写真を付置させた*。

以上に示した分類方法の抽出から軸の決定，重要度評価，評価 軸への写真布置の一連の作業を, 表 1 に示す各段階ごとに繰り返 し行った。ただし例外として，第 1 段階と第 2 段階は外部からの 情報が全くない状態での評価軸を抽出するために途中で写真を見 せることを避け,これらの段階における評価軸への写真の布置は, 第 3 段階でまとめて一緒に行った。

\footnotetext{
* 評価軸沈実際に被験者が写真を布置寸ることができたもののみを示しているため, 言葉で挙价れても除かれているものがある。
}

\section{3 面接実験の結果と考察}

\section{3 .1 属性間に見られる重要事項の差異}

面接の結果得られた, 被験者が普段から意識しているオフィス 照明の要件, オフィス照明の分類方法, 年真や教科書的な知識を 与えられることで喚起されたオフィス照明の分類方法の全分類視 点をもとに，79項目の照明に関寸る言葉を抽出し（表３）紙面に 布置した。これらの言葉を総じて細分類視点と呼ぶことにする. 被験者から得られた全細分類視点の中には，複数の細分類視点を 代表するような言葉が見られた (図 2 中灰色部分)。これらの言葉 は14項目に集約することができ，カテゴリーと呼ぶことにした(表 3 黒色).そしてカテゴリーと被験者が言及した言葉の関係を視覚 的に把握するためにそれぞれを線で結んでいく.例之ば四 2 には，

「明るさ」をブレークダウンすると「周辺の明るさ，手元の明る 


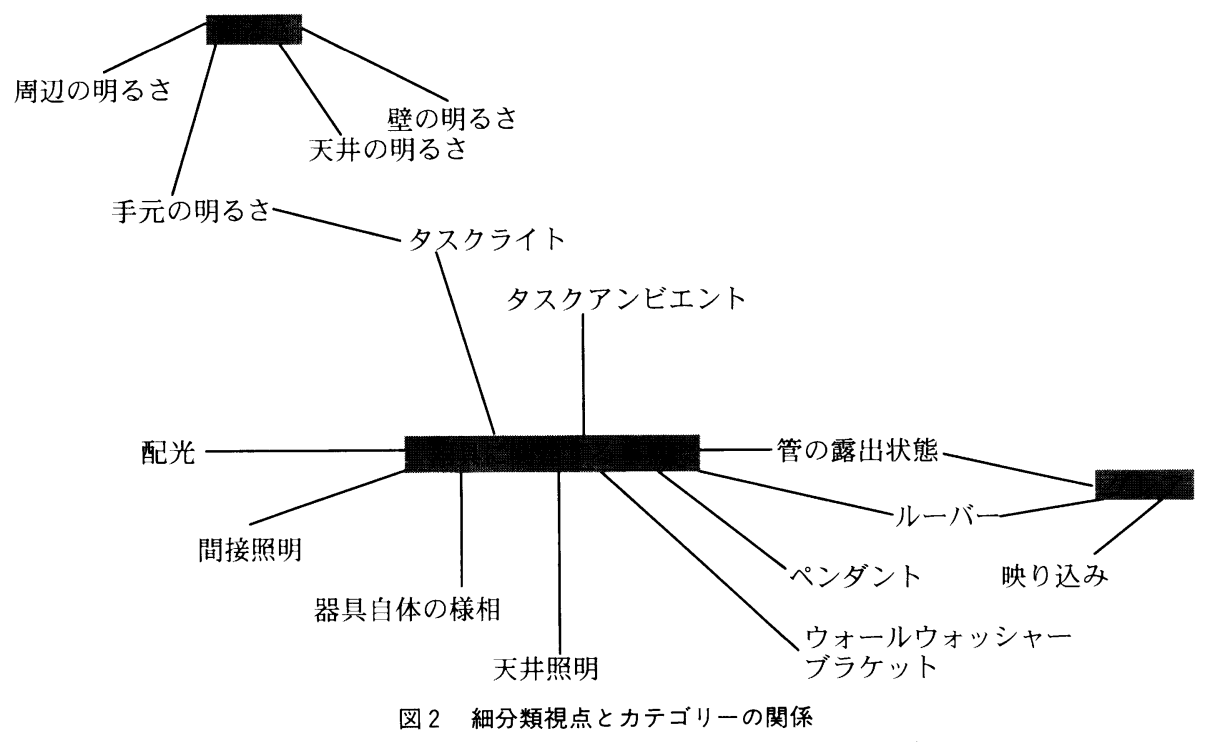

Fig. 2 The rerationship of small view points and categories.

点

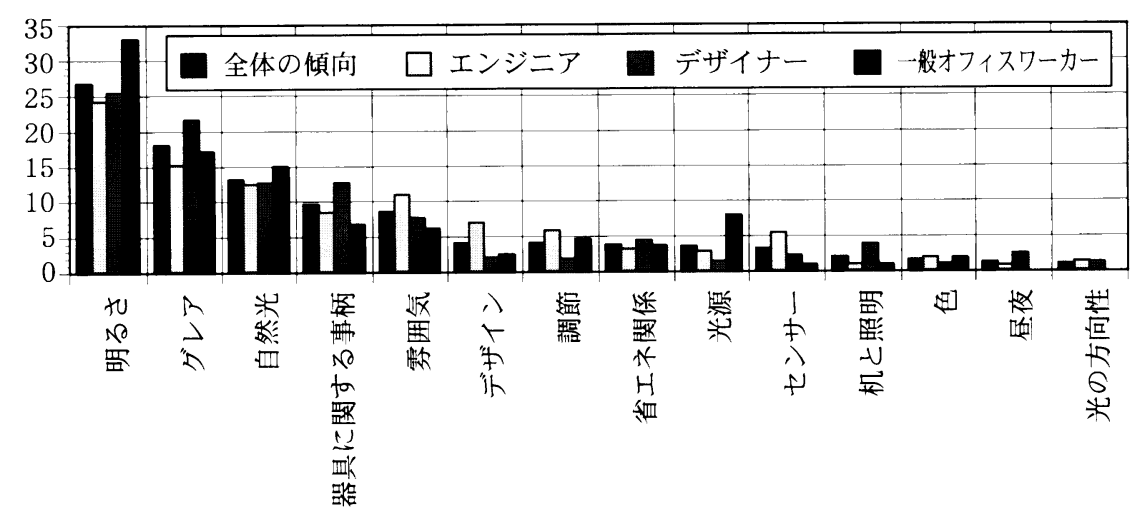

図 3 各カテゴリーの属性別重要度（100点満点）

Fig. 3 Importance evaluation of categories (mark them out of 100).

さ，天井面の明るさ，壁の明るさがある」と被験者が答えた結果 が示されている。このような作業を全ての被験者について行った ところ, カテゴリー同士は細分類視点を介して結ばれ，また，細 分類視点は全て，いずれかのカテゴリーにつながるようなネット ワークが得られた。以下これをネットワーク図と呼ぶ。尚「調節」 は，被験者が述べた文脈から「自分でする調節」であり，今ある 状態を変えることに主眼をおいて言及されていたのに对し，「ン サ一」は光センサなどのように明るさを一定に保つことに限定し ていたので，ここではあえて異なるカテゴリーーとした。

カテゴリーにつながる全ての細分類視点の重要度を合計するこ とで各カテゴリーの重要度を求め, 属性間の差異を見た（図 3 ）。 得点の算出方法を以下に示す。まず被験者の属性ごとに, 各力テ ゴリーにつながる各紐分類視点の重要度を「必要不可欠なくらい 重要」=4 点「かなり重要」=3 点「ふつうに重要」=2 点「あれば いい」=1点として合計し，それを属性ごとの被験者数で除し，そ の属性に扔いて被験者一人当たりがどの程度そのカテゴリーを重 視しているかを算出した。ここでそのカテゴリーにつながる細分 類視点に誰一人として触れなかった場合はそのカテゴリーの重要 度は 0 点になる．またカテゴリーにつながる各細分類視点の数が 多く，かつそれが重要であると評価されるほどそのカテゴリーの
重要度は上がる。次に各カテゴリーの得点を14項目全てのカテゴ リーの合計点で除し，それを100分率で表すことで標準化を行い， これを最終的な各カテゴリ一の重要度とした，尚，紐分類視点が 複数のカテゴリーに重複した場合は，その重要度を重複した全て のカテゴリーの重姴度に加算した。

全体の傾向として重要とされている事項は，14项目中上位半分 以上のものを見ると，上から「明るさ」「グレア」「自然光」「器具」 「雲讲気」「デザイン」「調節」である。各属性とも上位三項目は 同じであるが，4番目に挙げられる項目はデザイナ一では「霑囲 匃」, エンジニアでは「器具に関連する事柄」, 一般オフィスワー カーでは「光源」であり, 重姴視する項目に属性による差異が現 れた。また調節は14項目中 7 位であり,これらの項目に比べ重要 度は高くない。

次に，前述のネットワーク四に重要度を加味した上で，そのつ ながりの属性間差異を見た(図 4 ). デザイナ一と一般オフィスワ 一カーにはエンジニアにはないタスクライトを介した「器具」と

「調節」のつながりが特徵的であるが，各力テゴリ一のつながり はあまりない。一方，エンジニアは他の属性に比べて重要度の点 の高かった「器具」が中心となって各カテゴリーとのつながりを 形成しているが,「調節」の重要度が 4 点未満で低い. エンジニア 


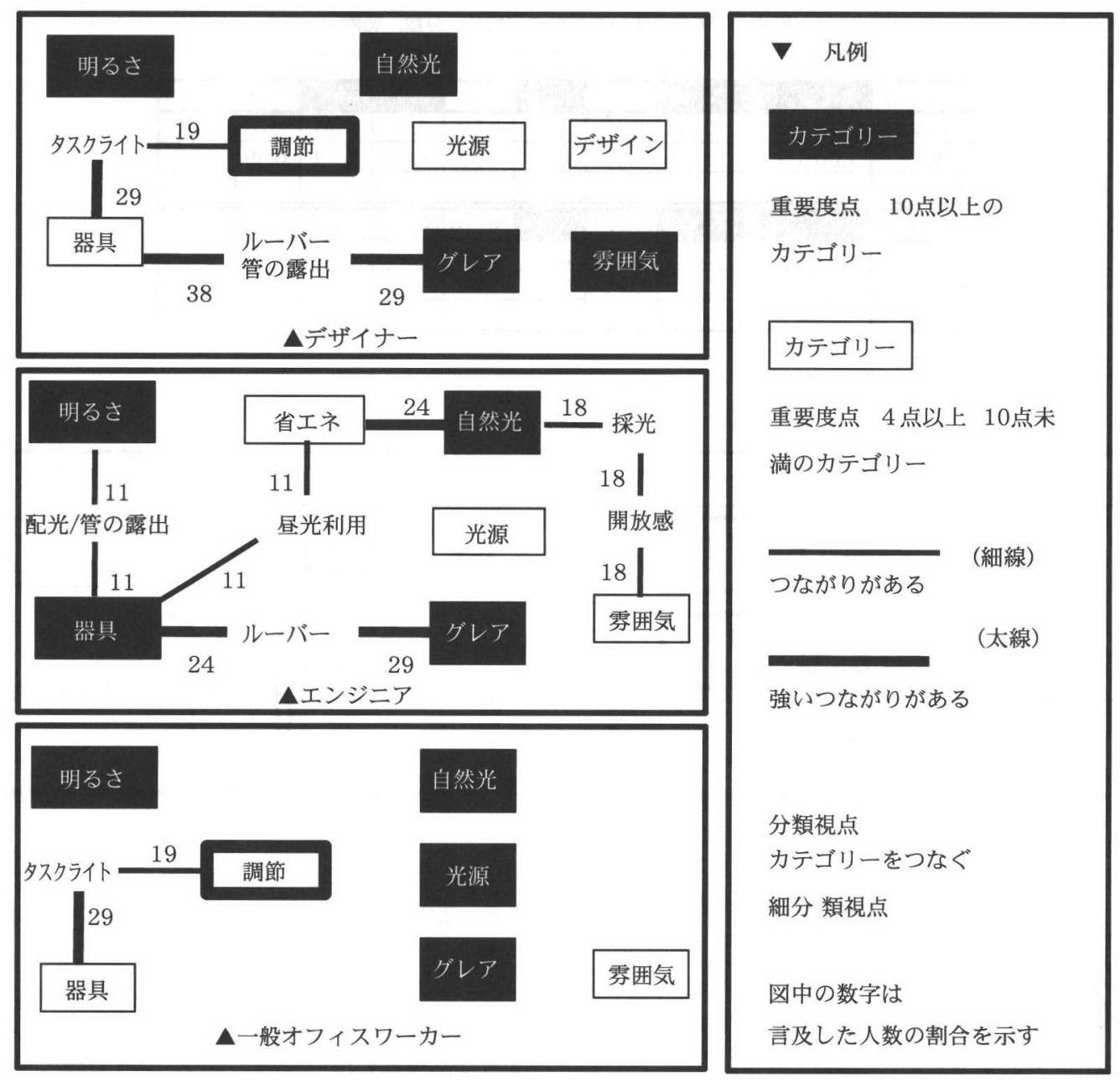

図 4 被験者の属性別簡易ネットワーク図

Fig. 4 The office light network of each property.

で器具や省エネが調節（調光）と結びついていないことについて の著者の見解を以下に示す。「調節」とは, 被験者の述べた文脈か ら「自分でする調節」で今ある状態を変えることに主眼をおいて 言及されていたので，エンジニアには，自分でする調節は必ずし も省エネに結びつくとは限らないという考え方が多いと思わる. 又「器具」に関しては, いわゆる照明器具に関しての言及が多か ったことから, まず照明器具がありきで「調光器 (調節)」はその 次の段階として存在するというように違った捉え方がされている と推測できる. 以上の理由からエンジニアでは器具や省エネが調 節（調光）と結びつかなかったと考えられる.

このように「調節」は非常に重要視されているわけではないが, デザイナーと一般オフィスワーカーにとっては，オフィス照明を 解釈しとらえる上で重要な役割を果たしていると考えられる.

\section{3 .2 被験者間に見られる各細分類項目の整合性}

19枚の写真評定の結果から, 各被験者の評価軸の整合性を見た。 14項目中もっとも重要とされた「明るさ」に関する評価軸では, 全被験者 55 人中 33 人が, 段階的評価が可能で適值があると言及し た.この評価軸を用いて19枚の写真を評定した結果を表 4 に示す が, 同じ写真でも評価のばらつきが大きく, 分散が 5 段階評価中 1 以上のあるものは, 黒地に白抜き文字で示したように, 全19枚 のうち 10 枚で半分以上もある. また殆どの写真で範囲が 5 段階評 価中 4 であり，これは被験者の布置した写真が「 1-4」または「2
- 5 」の 4 段階分にまたがって布置されているということを意味し ている。このことから各被験者によって明るさの評価のしかたは 異なり，かなり差があることが分かる.

このようにたとえ「明るさ」のような共通して抽出される尺度 であっても, 被験者間差異は大きく, それを吸収するための手段 の一つとしても, 個々人の好みに応じて照明環境を調節すること は重要であることが分かる.

以上「調節」は, 重要度評価では14項目中 7 位であるものの, 特にデザイナーと一般オフィスワーカーにとっては, オフィス照 明を解釈し認識する上で重要な役割を果たしており, また個人差 に対応する必要があることからもその重要性が高いことが明らか になった。そこで次にオフィス照明の明るさ調節が主観的評価に どの程度効果を与えているかを定量的に検討するための実験を計 画した。

\section{5. 明るさ調節効果の定量的検討のための実験}

\section{1 実験の概要}

オフィスを模し昼光を遮断した実験室にて, 表 5 に示す手順で 実験を進めた。手順は以下の通りである。まず表 5 の『調節あり』 では, 各種照明パターン（表 6 ）を提示し順応後, 後で調節がで きることを教示して, 次に作業（クレペリン計算作業）を60秒間 行わせ表 7 に示す評価項目を 7 段階評価で主観評価させた。そし 
表 4 明るい一暗いの評価の平均値, 分散, 範囲

Table 4 The mean, variance and range of light-dark rating score.

\begin{tabular}{|c|c|c|c|c|c|c|c|c|c|c|}
\hline 写真番号 & No.1 & $N 0.2$ & $N o .3$ & No.4 & $N(5.5$ & No.6 & $N_{0}(. \overline{7}$ & $\therefore 0.8$ & No.9 & No.10 \\
\hline 平均値 & 3.74 & 2.77 & 3.56 & 3.19 & 2.45 & 3.59 & 3.28 & 3.56 & 2.78 & 3.27 \\
\hline 分散 & 1.00 & 1.11 & 1.03 & 0.67 & 1.92 & 0.89 & 1.05 & 1.29 & 0.89 & 0.96 \\
\hline 範囲 & & & & & & & & & & \\
\hline 写真番号 & $\overline{N_{0.11}}$ & $\overline{\mathrm{N}} \overline{\mathrm{N} .12}$ & $\overline{N(1.13}$ & No.14 & $\overline{N(1) .1 .}$ & No.16 & No.17 & $\overline{\text { No.18 }}$ & No.19 & \\
\hline 平均値 & 2.87 & 3.71 & 2.33 & 2.72 & 2.26 & 1.81 & 1.44 & 1.61 & 1.61 & \\
\hline 分散 & 1.18 & 1.41 & 1.40 & 0.79 & 1.26 & 0.61 & 0.71 & 0.91 & 0.98 & \\
\hline 範用 & & & & & & & & & & \\
\hline
\end{tabular}

表 5 実験手順

Table 5 Experimental plan.

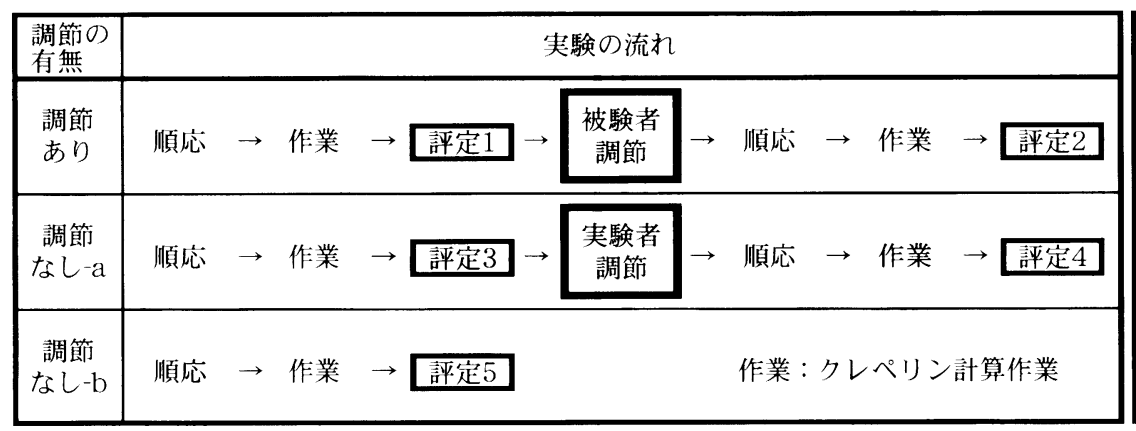

\begin{tabular}{|l|l|}
\hline 評定 1 & $\begin{array}{l}\text { Cognitive control+ } \\
\text { 調節前の定常 }\end{array}$ \\
\hline 評定 2 & $\begin{array}{l}\text { behavioral control+ } \\
\text { 変化+調節後の定常 }\end{array}$ \\
\hline 評定 3 & 調節前の定常 \\
\hline 評定 4 & 変化+調節後の定常 \\
\hline 評定 5 & 調節後の定常 \\
\hline
\end{tabular}

表 6 照明パターン

Table 6 Lighting patterns.

\begin{tabular}{|c|c|c|}
\hline \multicolumn{3}{|c|}{ 照明パターン } \\
\hline & $\begin{array}{l}\text { 初期設定の 全般で300lx } \\
\text { 机上面照度 }\end{array}$ & $\begin{array}{l}\text { MIM300lx } \\
\text { MAX700lx }\end{array}$ \\
\hline A & $\begin{array}{ll} & \text { 全般のみ調節で } \\
3 \text { 段調光 } & 3001 x \rightarrow 5001 x \\
& 3001 x \rightarrow 7001 x \\
& 5001 x \rightarrow 7001 x\end{array}$ & 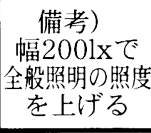 \\
\hline & $\begin{array}{l}\text { 初期設定の 全般で3001x } \\
\text { 机上面照度 タスクライトで } 01 x \\
\end{array}$ & $\begin{array}{l}\text { MIM300 } \\
\text { MAX700 } \\
\end{array}$ \\
\hline $\mathrm{B}$ & $\begin{array}{ll} & \text { タスクライトのみ調節で } \\
\text { 3段調光 } & 01 \mathrm{l} \rightarrow 2001 \mathrm{x} \\
& 01 \mathrm{x} \rightarrow 4001 \mathrm{x} \\
& 2001 \mathrm{l} \rightarrow 4001 \mathrm{x}\end{array}$ & $\begin{array}{c}\text { 備考) } \\
\text { 幅2001xで } \\
\text { 夕スクライトの } \\
\text { 照度を上げる } \\
\end{array}$ \\
\hline & \begin{tabular}{|l|} 
初期設定の 全般で700lx \\
机上面照度 吕クイトで400lx
\end{tabular} & $\begin{array}{l}\text { MIM700lx } \\
\text { MAX1100lx } \\
\end{array}$ \\
\hline $\mathrm{C}$ & $\begin{array}{ll} & \text { タスクライトのみ調節で } \\
\text { 3段調光 } & 4001 \mathrm{x} \rightarrow 2001 \mathrm{x} \\
& 2001 \mathrm{x} \rightarrow 01 \mathrm{x} \\
& 4001 \mathrm{x} \rightarrow 01 \mathrm{x}\end{array}$ & $\begin{array}{c}\text { 備考) } \\
\text { 幅2001xで } \\
\text { タスクライトの } \\
\text { 照度を下げる }\end{array}$ \\
\hline
\end{tabular}

表 7 評価項目

Table 7 The evaluation items.

\begin{tabular}{|l|l|l|l|}
\hline No1 & 作業面の明るさ & No8 & 天井照明の調節不要度 \\
\hline No2 & 天井面の明るさ & No9 & 手元照明の調節不要度 \\
\hline No3 & 座席対向壁面の明るさ & No10 & 作業のしやすさ \\
\hline No4 & 作業面の好ましさ & No11 & 目に負担のかからない度合い \\
\hline No5 & 作業面の調節不要度 & No12 & やる気度合い \\
\hline No6 & 部屋全体の好ましさ & No13 & 集中しやすさ \\
\hline No7 & 部屋全体の調節不要度 & No14 & 満足度 \\
\hline
\end{tabular}

て実験者は必要であれば調光できる旨を被験者に伝え, 被験者は 予め実験者が設置した調光器で全般照明のみ, 又は夕スクライト のみを調節した。そして再び60秒間の作業・主観評価をさせる。同

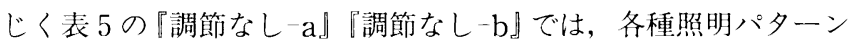

（表 6 ）を提示し順応後，調節ができないと教示し，作業と主観 評価（表7）をさせた。つまり『調節なしーa』『調節なしーb』では, 調節は行わせなかった。

被験者数は 11 人（男 6 人，女 5 人，年㱓 $21 \sim 30$ 歳）一回の実験 時間は約2.5時間である。提示守る照明パ夕ーン・調節する部位の 順番は乱数表を用いて決定した。調光は全ての被験者の調光照度 を同じにするために，段調光を採用した，尚，被験者は実験前に 実際に実験で使用する調光状態を幾つか体験し，調光にある程度 慣れた状態で実験を開始した。実験で用いた装置を表 8 に示す。

本実験では control の効果とある照明の状態での評価との間に 加法則が成立していると仮定した．表 5 に示寸評定 $1 ， 2 ， 3$ ， 4, 5 の control の状態揖よび評価值は次のようになる.

(1) 評定 1 ：被験者がこれから公内照明の調節ができると知って いながらまだ調節していない状況下での詊定なので「perceived control あり」の状況での評定. 評価は perceived control の効果 と調節前の定常状態の評価の合計であると考えられる.

(2) 評定 2 : 被験者が室内照明を調光した後の評定なので「behavioral control あり」の状況の評定. 評価は調節後の定常状態の 評価と behavioral control の効果と照度変化の効果の合計である と考えられる。

(3) 評定 3 : 被験者は実験者側から子予調節できないと告げられ るため「control なし」の状況の評定. 特にここでの定常状態は, 評定 1 の調節する前の状態と同じなので, 評価は調節前の定常状 態の評価.

(4) 評定 4 : 評定 4 の室内照明環境は, 調節後の評定である評定 2 を行った照明環境と全く同じものであるが，ここでは実験者が調 節している状況を被験者は見せられており，かつ被験者は照明の 明るさの変化のみを見るように指示されているため, 「 control な し」の状況の評定. 評価は調節後の定常状態の評価と照度変化の 効果との合計であると考えられる。

(5) 評定 5 : 被験者は実験者側から予如調節できないと告げられ 
表 8 実験装置

Table 8 The apparatus of the experiment.

\begin{tabular}{|c|c|c|}
\hline & \begin{tabular}{|c|} 
器具 \\
\end{tabular} & 設置箇所・備考 \\
\hline 全般照明 & $\begin{array}{l}\text { National 調光管FLR-40S・W/M（安定器使用） } \\
\text { 白色ラピッドスタート }\end{array}$ & $\begin{array}{l}\text { 40W蛍光ランプ2灯用で8灯天井面設置。マスターを } \\
\text { 使用して括調光 }\end{array}$ \\
\hline 全般照明用調光器 & $\begin{array}{l}\text { National 畄光灯用マスターライコン( } 4 \text { 回 } \\
\text { 路用)NQ20581-322 }\end{array}$ & 壁面設置だったものをコードを延長して手元に設置 \\
\hline タスクライト & Toshiba白熱灯100V100W & $\begin{array}{l}1 \text { 灯 } \\
\text { 床面設置で、光源の高さは机上面より } 500 \mathrm{~mm} \text { とした } \\
\text { 色温度補正のため青色フィルターかた }\end{array}$ \\
\hline タスクライト用調光器 & 陎卜ヨス夕一白熱灯用調光器Lucon & 手元設置 \\
\hline
\end{tabular}

るため「control なし」の状況の評定. 特にここでの定常状態は, 評定 2 の調節した後の状態と同じなので, 評価は調節後の定常状 態の評価.

以上から, 評定 1 の評価值から評定 3 の評価值を減ずることに より, perceived controlの効果が定量化でき, 評定 4 の評価值か ら評定 2 の評侢值を減ずることにより, behavioral controlの効 果が定量化でき, 評定 4 の詊価值から評定 5 の評価値を減ずること により，照度変化の効果が是量化できる。

尖験で得られたデ一夕を用いて，一対の標本による平均の $t$ 検 定（片側）を行った。評価の全体的な評価は, 表 7 の評価項目の No. 4 作業面の好ましさから No.14満足度の平均值で表されると した．以下，5.2，5.3節も同様である．表 9 に結果を示寸。

調節前後の評価の違いを表10に示守。照度を上げる時は, 調節 後の評価は調節前より上がる傾向にあり, 特に初期照度が低い300 $1 \mathrm{x}$ の時に $1 \%$ 有意で上がった. しかし初期照度が500 lxの場合 は，予め視作業ができる状態であったためか初期照度300 lx より も評価の上がり方が小さ $5 \%$ 有意であった。又，照度を下げる 時は調節後の評価は調節前より下がる傾向にあったが, 調節前後 で評価に有意差はなく, これは, 予め机上面照度が $1100 \mathrm{~lx}$ に照明 されている状態も, 調節後の机上面照度が900 lx 又は700 lx に照 明されている状態も，視作業が充分できる状態なので，調節して も効果が感じられなかったためであると推察できた，調節の効果 が現れるには, 初期状態が悪く調節が必要とされる状態であるこ とが重要であることになる。

\section{2 初期照度による perceived control の効果}

ここでは同じ照明状態が，必要であればこれから照明が調節で きると言う perceived controlによってどの程度評㑛が変わるか を示古 (表11).

全般照明の照度を上げる調節（照明パターンA）では，全般照 明で机上面照度が300 lx に照らされている状態から，全般照明を 調光して照度を更に $200 \mathrm{~lx}$ 上げて500 lxにできる，又は更に400 $1 \mathrm{x}$ 上げて7001xにできるという perceived control (評価值 7 点満 点中 +0.18 (以下 +0.18$) ， 5 \%$ 有意)，全般照明で机上面照度が $5001 \mathrm{x}$ に照らされている状態から，全般照明を調光して照度を更 に200 lx 上げて700 lxにできるという perceived control (+ 0.28 ，有意差なし）は，ともに評価を上げる効果がある。

タスクライトの照度を上げる調節（照明パターン B）では，全 般照明で机上面照度が300 lx に照らされている状態から，タスク ライトを調光して照度を200 lx 上げて合計で500 lx にできる，又 は400 lx 上げて合計700 lx にできるという perceived control は 正の効果があるが $(+0.10$, 有意差なし $)$, 全般照明で机上面照度 が300 lx に照らされ更にタスクライトで200 lx 照らされている状 態から，そのタスクライトを調光して更に照度を200 lx 上げて合 計700 lxにできるといj perceived control は負の効果がある (-0.45, 有意差なし).これは, 前者は夕スクライトが点いてい
ない状態なので，被験者は夕スクライトを明るくすると初期状態 の溥暗い状態が厙くなると子测したと思われるが，後者のように タスクライトが点灯しているとそのタスクアンビエント比が気に なり，被験者はこれ以上タスクライトを明るくすると照明の明る さのバランスが悪くなる可能性があると判断したためだと考えら れる.

タスクライトの照度を下げる調節 (照明パターンC)では，机上 面照度が全般照明で700 lx に照らされ更にタスクライトで200 lx 照明さている状態から，タスクライトを調光して照度を200 lx 下 げて合計700 lx にできる perceived control は正の効果があるが $(+0.42$, 有意差なし), 机上面照度が全般照明で700 lxに照らさ れ更にタスクライトで $400 \mathrm{~lx}$ 照明さている状態から， タスクライ 卜を調光して照度を $200 \mathrm{~lx}$ 下げて合計 $900 \mathrm{~lx}$ にできる，又は400 1x下げて合計700 lx にできるという perceived control は負の効 果がある(ー0.08, 有意差なし)。前者は，実験中に少しだけ夕ス クライトがついている状態ならば消した方がよいという被験者も いたことから, perceived control が正に働いたと解僠できる。後 者については明るく点灯しているものを暗くできるということに 対して不満を感じる被験者が多かったと推測できる.

このように perceived control は, 全般照明の照度を上げられる 場合は正に働き，タスクライトの照度を上げられる場合は初期状 態のタスクアンビエント比が影䈉すると考えられた。また夕スク ライトの照度を下げられるという perceived control は, 夕スクラ イトが明るく点灯している場合は暗くなるという印象が強いため か評伴を下げる一ヶで，少しだけついている状態ならば消した方 がよいと判断され評価を上げると推测できた。

\section{3 behavioral control と照度变化の効果}

behavioral control と照度変化の効果を表12に示す。全体的な 傾向を以下に述べる.

全般照时の照度を上げる調節 (照明パターン A)では, behavioral control, 照度変化は共に評価を上げる効果がある. behavioral control の効果は400 lx 上げる時のみ $5 \%$ 有意で照度変化の効果 に有意差はない.

タスクライトの照度を上げる調節（照明パターン B ）では, behavioral control は評価を下げ，照度変化は評価を上げる効果が ある，照度変化のみを与えられた時は明るくなるほど良くなると いう一般的な評価がされている一方で，目分が明るさの変化に関 与し調光すると, 被験者が「周りの明るさに比べてタスクライト の明るさが気になる」と言及したことから，照度変化のみを与之 られた時より同じ光環境に対して厳しく評䛧する効果が behavioral controlにあると考えられる。尚, behavioral control と 照度変化の効果に有意差はない。

タスクライトの照度を下げる調節（照明パターンC）では，behavioral control は評価を上げ，照度変化は評価を下げる効果が ある．照度変化のみを与えられた時は暗くなるほど覀くなるとい 
表 9 control と照度变化の効果

Table 9 The effect of control and change in illumination level.

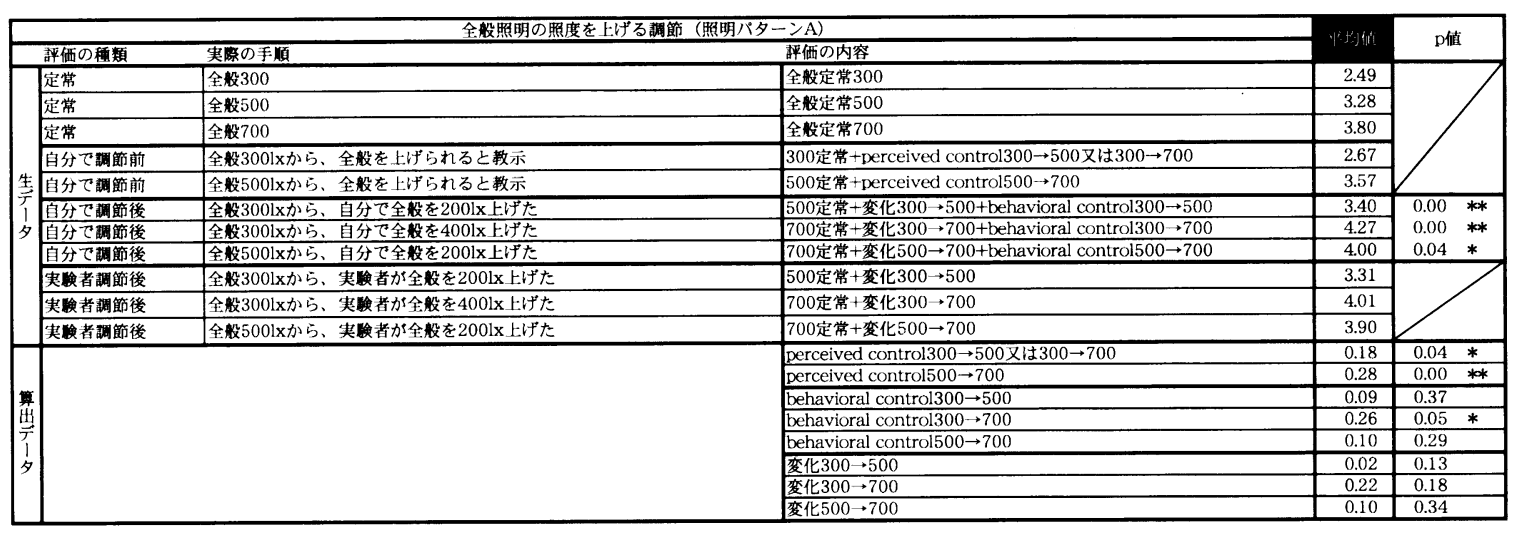
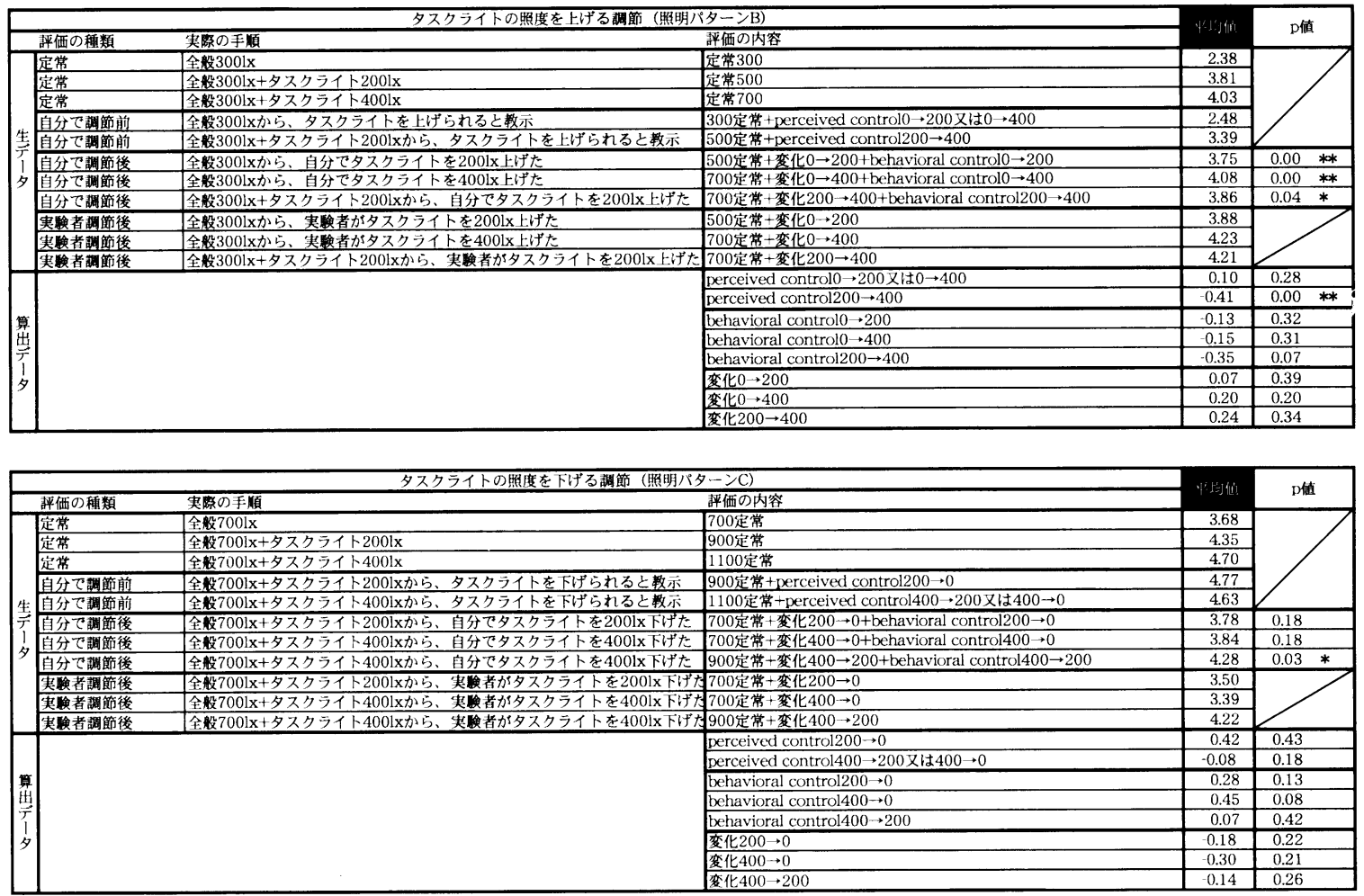

表10 調節前後の評価の違い

Table 10 The rating score before and after lighting adjustment.

\begin{tabular}{|c|c|c|c|c|c|c|c|c|}
\hline \multicolumn{3}{|c|}{ 全般照明を上げる(パターンA) } & \multicolumn{3}{|c|}{ タスクライトを上げる(パターンB) } & \multicolumn{3}{|c|}{ タスクライトを下げる(パターンC) } \\
\hline $\begin{array}{c}\text { 白分で調節前 } \\
\text { 全般 } 300 \\
\text { 評価値 } 2.67\end{array}$ & $2001 x$ & $\begin{array}{c}\text { 自分で調節後 } \\
\text { 全般 } 500 \\
\text { 評価値 } 3.40 * *\end{array}$ & $\begin{array}{l}\text { 自分で調節前 } \\
\text { 全般 } 300 \\
\text { 評価値 } 2.48\end{array}$ & $\underset{\longrightarrow}{2001 x}$ & \begin{tabular}{|c|} 
自分で調節後 \\
全般 300 タ 2 タ 200 \\
評価値3.75** \\
\end{tabular} & $\begin{array}{c}\text { 自分で調節前 } \\
\text { 全般700多 } \\
\text { 評価値 } 4.63 \\
\end{array}$ & $2001 \mathrm{x}$ & 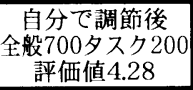 \\
\hline $\begin{array}{c}\text { 自分で調節前 } \\
\text { 全般 } 300 \\
\text { 謤価値 } 2.67\end{array}$ & $400 l x$ & $\begin{array}{l}\text { 自分で調節後 } \\
\text { 全般 } 700 \\
\text { 評価值 } 4.27 * *\end{array}$ & $\begin{array}{l}\text { 自分で調節前 } \\
\text { 全般 } 300 \\
\text { 評価値 } 2.48\end{array}$ & 4001x & \begin{tabular}{|c|} 
自分で調節後 \\
全般300多 \\
評価値4.08** \\
\end{tabular} & $\begin{array}{c}\text { 自分で調節前 } \\
\text { 全般700夕夕 } \\
\text { 評価値4.63 } \\
\end{array}$ & $4001 x$ & $\begin{array}{c}\text { 自分で調節後 } \\
\text { 全般700夕タク } 00 \\
\text { 評価値 } 3.84\end{array}$ \\
\hline $\begin{array}{c}\text { 自分で調節前 } \\
\text { 全般500 } \\
\text { 評価値 } 3.57\end{array}$ & $2001 \mathrm{x}$ & $\begin{array}{c}\text { 自分で調節前 } \\
\text { 全般 } 700 \\
\text { 評価値 } 4.00 *\end{array}$ & $\begin{array}{c}\text { 自分で調節前 } \\
\text { 全般 } 300 \text { 夕夕スク } 200 \\
\text { 評価値 } 3.39\end{array}$ & $\underset{\longrightarrow}{2001 \mathrm{x}}$ & \begin{tabular}{|c|} 
自分で調節前 \\
全般 300 夕スク 400 \\
詊価值 $3.86 *$
\end{tabular} & $\begin{array}{c}\text { 自分で調節前 } \\
\text { 全般700多ス } 200 \\
\text { 評価值 } 4.77\end{array}$ & $2001 x$ & $\begin{array}{c}\text { 自分で調節前 } \\
\text { 全般700タ } \\
\text { 評価值 } 3.78\end{array}$ \\
\hline
\end{tabular}


表11 cognitive control の効果

Table 11 The effect of cognitive control.

\begin{tabular}{|c|c|c|c|c|c|c|c|c|}
\hline \multicolumn{3}{|c|}{ 全般照明を上げる（パターンA） } & \multicolumn{3}{|c|}{ タスクライトを上げる (パターンB) } & \multicolumn{3}{|c|}{ タスクライトを下げる（パターンC） } \\
\hline 定常 & cognitive & 自分で調節前 & 定常 & cognitive & 自分で調節前 & 定常 & cognitive & 自分で調節前 \\
\hline 全般300 & $\begin{array}{c}\text { control } \\
\downarrow+0.18 *\end{array}$ & $\begin{array}{c}\text { 全般300 } \\
\text { cognitive control }\end{array}$ & 全般300 & $\begin{array}{c}\text { control } \\
+0.10\end{array}$ & $\begin{array}{c}\text { 全般300 } \\
\text { cognitive control }\end{array}$ & 全般700夕スク 200 & $\begin{array}{c}\text { control } \\
++0.42\end{array}$ & $\begin{array}{l}\text { 全段700夕スク } 200 \\
\text { cognitive control }\end{array}$ \\
\hline 評価値 2.49 & & 評価値 2.67 & 評価値 2.38 & & 評価值 2.48 & 評価値4.35 & & 評価値4.77 \\
\hline 定常 & cognitive & 自分で調節前 & 定常 & cognitive & 自分で調節前 & 定常 & cognitive & 自分で調節前 \\
\hline 全般500 & $\begin{array}{c}\text { control } \\
+028 * *\end{array}$ & $\begin{array}{c}\text { 全般500 } \\
\text { cognitive control }\end{array}$ & 全般300夕スク 200 & $\begin{array}{c}\text { control } \\
-041 * *\end{array}$ & $\begin{array}{l}\text { 全般 } 300 \text { 夕スク } 200 \\
\text { cognitive control }\end{array}$ & 全般700夕スク 400 & control & $\begin{array}{l}\text { 全般700夕スク } 400 \\
\text { cognitive control }\end{array}$ \\
\hline 評価値 3.28 & & 評価值 3.57 & 評価値3.81 & & 評価値3.39 & 評価値4.70 & & 評価値4.63 \\
\hline
\end{tabular}

表12 behavioral control と変化の効果

Table 12 The effects of behavioral control and change in luminance level.

\begin{tabular}{|c|c|c|c|}
\hline 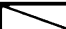 & 評価の内容 & 萪価の增城 & p值 \\
\hline \multirow{4}{*}{ 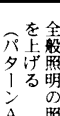 } & behavioral control $300 \rightarrow 500$ & 0.09 & 0.37 \\
\hline & behavioral control $300 \rightarrow 700$ & 0.26 & 0.05 \\
\hline & behavioral control $500 \rightarrow 700$ & 0.10 & 0.29 \\
\hline & 変化 $300 \rightarrow 500$ & 0.02 & 0.13 \\
\hline \multirow{2}{*}{ A 盟 } & 府化 $300 \rightarrow 700$ & 0.22 & 0.18 \\
\hline & 度化 $500 \rightarrow 700$ & 0.10 & 0.34 \\
\hline \multirow{6}{*}{ 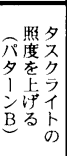 } & behavioral control $0 \rightarrow 200$ & -0.13 & 0.32 \\
\hline & behavioral control $\rightarrow \rightarrow 400$ & -0.15 & 0.31 \\
\hline & behavioral control $200 \rightarrow 400$ & -0.35 & 0.07 \\
\hline & 度化 $0 \rightarrow 200$ & 0.07 & 0.39 \\
\hline & 变化 $0 \rightarrow 400$ & 0.20 & 0.20 \\
\hline & 㢇化 $200 \rightarrow 400$ & 0.24 & 0.34 \\
\hline \multirow{6}{*}{ 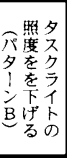 } & behavioral control $200 \rightarrow 0$ & 0.28 & 0.13 \\
\hline & behavioral control $400 \rightarrow 0$ & 0.45 & 0.08 \\
\hline & behavioral control $400 \rightarrow 200$ & 0.07 & 0.42 \\
\hline & 怼化 $200 \rightarrow 0$ & -0.18 & 0.22 \\
\hline & 度化 $400 \rightarrow 0$ & -0.30 & 0.21 \\
\hline & 膺化 $400 \rightarrow 200$ & -0.14 & 0.26 \\
\hline
\end{tabular}

う一般的な評価がされている一方で，自分が明るさの変化に関与 すると，被験者が「タスクライトは消したい」と言及したことか ら, behavioral controlには，より細かに環境を見ながら調光し， 照度変化のみを与えられた時より良くなった点を過大評価させる 効果があるためと考えられる，尚， behavioral control と照度変 化の効果に有意差はない.

以上から，全般照明の照度を上げられる時は，照度変化， behavioral control 共に評価を上げる効果があるが， タスクライト の照度を変えられる時は，照度変化は照度が上がる程良いという

一般的な評価がされる一方で, behavioral control は照度を上げ る時は評価を下げる効果があり，下げる場合は良くなった点を過 大評価させる効果があると考えられた。

\section{3 .1 照度の上げ幅，下げ幅の違いによる} behavioral control と照度変化の効果

初期の照明状態が同じであるが，照度の上げ幅（又は下げ幅） が200 lx 又は400 lx と異なるもの同士を比較し，照度変化量によ る behavioral control と照度変化の効果の差を見る（表13）。

全般照明の照度を上げる調節（照明パターンA）では，全般照 明で机上面照度が300 lx に照らされている状態から，全般照明を 調光して照度を更に200 lx 上げて500 lx にする（以下 $2001 \mathrm{~lx}$ 上げ る／behavioral control +0.09 , 照度変化 +0.02$)$ より，更に 400 $\mathrm{lx}$ 上げて700 lx にする（以下 $400 \mathrm{~lx}$ 上げる／behavioral con trol +0.26 , 照度変化 +0.22$)$ 方が, 有意差はないが効果が高い. より作業に適した状態にできるため $400 \mathrm{~lx}$ 上げる方が照度変化， behavioral control ともに効果が高いと考えられる.

タスクライトの照度を上げる調節（照明パターン B）では， behavioral control は，全般照明で机上面照度が300 lx に照らされ ている状態から，タスクライトを調光して照度を2001x 上げて合
表13 上げ幅下げ幅の違いによる behavioral control と変化の効果 Table 13 The rating score difference of behavioral control and change in luminance level according to range of raising and dimming lighting.

\begin{tabular}{|c|c|c|c|}
\hline & 評価の内容 & 評価の増減 & $\mathrm{p}$ 值 \\
\hline \multirow{4}{*}{$\begin{array}{l}\text { 全般照明 } \\
\text { を } 3001 x \\
\text { から上げる } \\
\text { (パターンA) }\end{array}$} & behavioral control $300 \rightarrow 500$ & 0.09 & 0.37 \\
\hline & behavioral control $300 \rightarrow 700$ & 0.26 & $0.05 *$ \\
\hline & 変化 $300 \rightarrow 500$ & 0.02 & 0.13 \\
\hline & 変化 $300 \rightarrow 700$ & 0.22 & 0.18 \\
\hline \multirow{4}{*}{$\begin{array}{c}\text { タスクライト } \\
\text { を300lxから } \\
\text { 上げる } \\
\text { (パターンB) }\end{array}$} & behavioral control0 $\rightarrow 200$ & -0.13 & 0.32 \\
\hline & behavioral control $0 \rightarrow 400$ & -0.15 & 0.31 \\
\hline & 変化 $0 \rightarrow 200$ & 0.07 & 0.39 \\
\hline & 変化 $0 \rightarrow 400$ & 0.20 & 0.20 \\
\hline \multirow{4}{*}{$\begin{array}{c}\text { タスクライト } \\
\text { を11001xから } \\
\text { 下げる } \\
(\text { パターンC) }\end{array}$} & behavioral control $200 \rightarrow 0$ & 0.28 & 0.13 \\
\hline & behavioral control $400 \rightarrow 0$ & 0.45 & 0.08 \\
\hline & 変化 $200 \rightarrow 0$ & -0.18 & 0.22 \\
\hline & 変化 $400 \rightarrow 0$ & -0.30 & 0.21 \\
\hline
\end{tabular}

計500 lx にする（以下 200 lx 上げる 一-0.13）より，400 lx 上げて 合計700 lx にする（以下 $400 \mathrm{~lx}$ 上げる/ - 0.15）の方が，有意差は ないが効果が低く，照度変化 $(200 \mathrm{~lx}$ 上げる $+0.07,400 \mathrm{~lx}$ 上げ る十0.20）はこれと逆である(有意差なし).400 lx 上げる方が， 照度変化の正の効果は大きく, behavioral control は夕スクアン ビエント比が大きくなるため負の効果が大きいと推察される.

タスクライトの照度を下げる調節（照明パ夕ーンC）では， behavioral control は，机上面照度が全般照明で700 lxに照らされ 更にタスクライトで400lx 照明さている状態から，タスクライト を調光して照度を $200 \mathrm{~lx}$ 下げて合計900 lx にする（200 lx 下げる ノ+0.28）より，400 lx 下げて合計700 lx にする（400 lx 下げる ノ+0.45）方が, 有意差はないが効果が高く, 照度変化はこれと 逆である（200 lx 下げるー0.18，400 lx 下げる-0.30，有意差な し).消した感覚が目に見えて大きい $400 \mathrm{~lx}$ 下げる方が照度変化の 負の効果は大きく, behavioral control はより過大に評価されて いると推察される。

初期照度が同じ時は，全般照明の照度を上げられる場合，夕又 クライトの照度を上げる下げる調節は共に, 照度変化量の多い 400 lx の方が200 lx より, 照度変化と behavioral control の効果が大 きいことが明らかになった。

\subsection{2 初期照度の違いによる behavioral control と 照度変化の効果}

ここでは照度の上げ幅（又は下げ幅）が200 lx で同じであるが， 初期の照度が異なるもの同士を比較して，初期状態によるbehavioral control と照度変化の効果について考察する（表14）. 
表14 初期照度の違いによる behavioral control と変化の効果

Table 14 The rating score difference of behavioral control and change in luminance level according to primly luminance level.

\begin{tabular}{|c|c|c|c|}
\hline & 評価の内容 & 評価の増减 & $\mathrm{p}$ 值 \\
\hline 全般照明 & behavioral control300 $\rightarrow 500$ & 0.09 & 0.37 \\
\hline \multirow{3}{*}{$\begin{array}{c}\text { を2001x } \\
\text { 上げる } \\
(\text { パターンA) }\end{array}$} & behavioral control $500 \rightarrow 700$ & 0.10 & 0.29 \\
\hline & 変化 $300 \rightarrow 500$ & 0.02 & 0.13 \\
\hline & 変化 $500 \rightarrow 700$ & 0.10 & 0.34 \\
\hline \multirow{4}{*}{$\begin{array}{c}\text { タスクライト } \\
\text { を2001x } \\
\text { 上げる } \\
\text { (パターンB }\end{array}$} & behavioral control0 $\rightarrow 200$ & -0.13 & 0.32 \\
\hline & behavioral control $200 \rightarrow 400$ & -0.35 & 0.07 \\
\hline & 変化 $0 \rightarrow 200$ & 0.07 & 0.39 \\
\hline & 変化 $200 \rightarrow 400$ & 0.24 & 0.34 \\
\hline \multirow{4}{*}{$\begin{array}{c}\text { タスクライト } \\
\text { を2001x } \\
\text { 下げる } \\
\text { (パターンC) }\end{array}$} & behavioral control $200 \rightarrow 0$ & 0.28 & 0.13 \\
\hline & behavioral control $400 \rightarrow 200$ & 0.07 & 0.42 \\
\hline & 変化 $200 \rightarrow 0$ & -0.18 & 0.22 \\
\hline & 変化 $400 \rightarrow 200$ & -0.14 & 0.26 \\
\hline
\end{tabular}

全般照明を調光して照度を $200 \mathrm{~lx}$ 上げる場合(照明パターン A) では，机上面照度が全般照明で300 lx に照明されている状態から 全般照明を200 lx 上げて500 lxにするより（behavioral control十 0.09 , 照度変化 +0.02$)$, 机上面照度が全般照明で5001xに照明さ れている状態から全般照明を200 lx 上げて700 lx にする方が（behavioral control +0.10 , 照度変化 +0.10$)$, 有意差はないが効果 が高い. 全般照明の調節は同じ $2001 \mathrm{x}$ 上げられるならば, 調節後に 得られた照度水準が behavioral control と照度変化の效果に大き な影響を与えると考えられる。

タスクライトを調光して照度を $200 \mathrm{~lx}$ 上げる場合（照明パ夕一 ン B）では， behavioral control は，机上面照度が全般照明で300 $1 \mathrm{x}$ に照明されている状態から夕スクライトを使って照度を200 lx 上げて合計500 lx にするより $(-0.13)$ ，机上面照度が全般照明で $300 \mathrm{~lx}$ に照明され更にタスクライトで200 lx 照明されている状態 からタスクライトのみを200 lx 上げて合計700 lx にする 方が有意差はないが効果が低く, 照度変化はこれと逆である（そ れぞれ $+0.07,+0.18$, 有意差なし). 同じ $200 \mathrm{~lx}$ 上げられる状態 で，照度変化はより明るい状態から更に明るくなることはより良 いことであると一般的な評価がされたため, 初期照度が高い方が 効果が高くなると推测できる，その一方で，自分が明るさの変化 に関わりを持つと，調節後の照度が高くできても光環境に対して 作業に適した環境にできたか否かをより厳しく評価しているた
め，この場合ではタスクアンビエント比が大きくならない初期照 度が低い方が behavioral controlの効果が高くなると伺える.

タスクライトを調光して照度を $2001 \mathrm{x}$ 下げる場合（照明パター ンC) では, behavioral control は机上面照度が全般照明で700 lx に照明され更にタスクライトで400 lx 照明されている状態から夕 スクライトのみ $200 \mathrm{~lx}$ 下げて合計 $900 \mathrm{~lx}$ にするより $(+0.45)$, 机 上面照度が全般照明で700 lx に照明され更にタスクライトで200 $1 \mathrm{x}$ 照明されている状態からタスクライトのみ $2001 \mathrm{x}$ 下げて合計 $700 \mathrm{~lx}$ にする方が $(+0.28)$ 有意差はないが効果が高く, 照度変化 はこれと逆である(それぞれ-0.30, - 0.18 , 有意差なし). 同じ $2001 \mathrm{x}$ 下げられる状態で, 照度変化は明るさが変わった後の照度 が少しでも高いままが良いという一般的な評価されたためか初期 照度が高い方が効果が高いと推測できる．その一方で, 自分が明 るさの変化に関わりを持つ場合は，実験中に被験者が「タスクラ イトを消したい」と言及したことから，この場合ではタスクライ 卜を完全に消灯できる初期照度が低い方が behavioral controlの 効果が高くなると思われる.

以上から, 全般照明を同照度だけ上げられる場合は, behavioral control と照度変化は共に正に働き調節後に得られた照度水準が 評価に大きな影響を与えると推測された，タスクライトを同照度 上げられる又は下げられる場合は, 照度変化は照度が変わった後 も少しでも明るい方が良いという一般的な評価された一方で，自 分が明るさの変化と関わりを持った時は調節後の光環境が作業に 適した状態になったか否かをより㛜しく評価し，本実験では作業 に適した状態になる可能性のある初期照度が低い方が behavioral control の効果が高くなる傾向にあると思われた.

\section{4 調節とオフィス照明の他の項目との関係}

被験者が調節をどのように捉えているかを明らかにするために 調節実験の前後に被験者に照明の調節に対してのアンケート調査 および教示を行った。

調節には，ただ単に暗い又は明るすぎるという理由から明るさ をかえるだけではなく, 省工ネのためや雲网気をかえるため, 光 に指向性を持たせるためなど椂々な目的がある。しかし人々は普 段からこれら全てを意識しているわけではないと考えられる。そ こでまず人々が日常生活において何のための調節を特に重視して いるかを明らかにした。そして，調節はその実体験を通じて初め て重視されるという仮定のもと, 実験前にはあまり重視されてい なかった目的のための調節が, 実体験を通じてどの位重視される ようになるかを把握した。アンケート調査および教示の内容は,

表15 明るさ調節実験前後のアンケート

Table 15 The interview before and after experiment of adjusting lighting.

\begin{tabular}{|c|c|c|c|}
\hline & No. & 質問内容 & 備考 \\
\hline \multirow{3}{*}{$\begin{array}{l}\text { 謇 } \\
\text { 前 } \\
\text { 前 }\end{array}$} & 贋問 1 & |冖照明の調節」には、どようなものがあると思われますか？ & \\
\hline & & 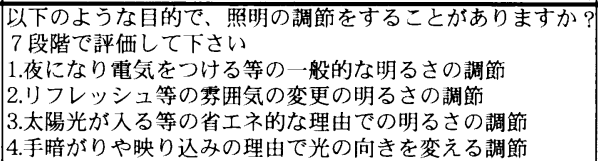 & $\begin{array}{l}7=\text { 日常的に非常によくする } \\
4=\text { =゙ちらともいえな } \\
1 \text { =日常的に全くしない }\end{array}$ \\
\hline & 質問 3 & 又その重要性をどう思われますか？7段階で評価して下さい & $\begin{array}{l}7=\text { 非常に重要 } \\
4=\text { 艺ちとえない } \\
1=\text { 全く重要ではない } \\
\end{array}$ \\
\hline \multirow{4}{*}{ 塞 } & 教示 1 & それではこの状態から照明を調節して下さい。 & $\begin{array}{l}\text { VDTに照明が映り込んでいる状 } \\
\text { 態からの調節 }\end{array}$ \\
\hline & 教示 2 & $\begin{array}{l}\text { それでは、この状態からリフレッシュするのに最適な状態 } \\
\text { に調節して下さい }\end{array}$ & $\begin{array}{l}\text { 室の照明を最大に明るくした状 } \\
\text { 態からの調節 }\end{array}$ \\
\hline & 教示 3 & それではこの状態から照明を調節して下さい。 & $\begin{array}{l}\text { 昼光を室に入れ、空際に近い席 } \\
\text { で調節させる }\end{array}$ \\
\hline & 質問 1 & $\begin{array}{l}\text { 以下のような目的での照明の調節の重要度を } 7 \text { 段階で評価 } \\
\text { して下さん }\end{array}$ & $\begin{array}{l}\text { 寒験前の缅問 } 2 \text { と同じ項目で同 } \\
\text { じ評価尺度 }\end{array}$ \\
\hline
\end{tabular}


表16 照明の調節で思いつくもの

Table 16 The variation of lighting adjustment which subjects said.

\begin{tabular}{|c|c|c|c|c|c|c|c|c|c|c|c|}
\hline 被験者の挙げた項目 & $\begin{array}{l}\text { 被験者 } \\
\text { NO.1 }\end{array}$ & $\begin{array}{l}\text { 被験者 } \\
\text { NO.2 }\end{array}$ & $\begin{array}{l}\text { 被験者 } \\
\text { NO.3 }\end{array}$ & $\begin{array}{l}\text { 被験者 } \\
\text { NO.4 }\end{array}$ & 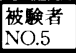 & $\begin{array}{l}\text { 被験者 } \\
\text { NO.6 }\end{array}$ & $\begin{array}{l}\text { 被験者 } \\
\text { NO.7 }\end{array}$ & $\begin{array}{l}\text { 被駩者 } \\
\text { NO.8 }\end{array}$ & \begin{tabular}{|l} 
被験者 \\
NO.9.
\end{tabular} & \begin{tabular}{|l} 
被験者 \\
NO.10
\end{tabular} & \begin{tabular}{|l} 
被験者 \\
NO.11
\end{tabular} \\
\hline 1夜に暗くなったら点灯 & 1 & 1 & 1 & 1 & 1 & & & 1 & 1 & 1 & 1 \\
\hline 2リビングの点灯消灯 & & & & & & & & 1 & & & \\
\hline 3 部屋に入って点灯 & 1 & & & & & 1 & & & & & 1 \\
\hline 4宿る前に消す & 1 & & & & & & & & & & \\
\hline 5 ベッドランプを点灯消灯 & & & & & & & 1 & & & & \\
\hline 6 リビングの照明を調節 & & & & & & & 1 & & & & \\
\hline 7机にライトを置く & & & & & & & & & 1 & & \\
\hline 8部屋の電気は檁る時は亘球だけにする & & & & & & 1 & & & & & \\
\hline 9力ラオケBoxで明るさをくるーつと調節 & & & & & & & & & 1 & & \\
\hline 1d モニターの明るさ調節 & & 1 & & & & & & & & & \\
\hline 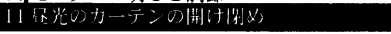 & & & & & & & & & & & \\
\hline
\end{tabular}

表17目的ごとの調節の日常的な実施頻度と実験前後の重要度

Table 17 The rating score of daily frequency and importance of each lighting adjustment before and after experiment.

\begin{tabular}{|c|c|c|c|c|c|}
\hline 評価項目 & $\begin{array}{l}\text { 実験前 } \\
\text { 日常 }\end{array}$ & $\begin{array}{l}\text { 実験前 } \\
\text { 重要度 }\end{array}$ & $\begin{array}{l}\text { 実験後 } \\
\text { 重要度 }\end{array}$ & $\begin{array}{c}\text { 実験前日常と } \\
\text { 重要度の差 } \\
\text { (日常-重要) }\end{array}$ & $\begin{array}{c}\text { 実験前後の重 } \\
\text { 要度の差 } \\
\text { (後-前) }\end{array}$ \\
\hline 一般的な明るさの調節 & 6.00 & 6.27 & 6.45 & $-0.27 *$ & 0.18 \\
\hline 雾囲気の変更 & 5.45 & 5.73 & 6.27 & $-0.27 \quad * *$ & $0.55 *$ \\
\hline 省エネ的な理由 & 4.82 & 5.64 & 5.73 & $-0.82 \quad * *$ & 0.09 \\
\hline 向きを変える & 5.45 & 5.73 & 6.27 & -0.27 & $0.55 *$ \\
\hline
\end{tabular}

表15のとおりである.

調節実験前に被験者が挙げた照明の調節で思い付く事項は表16 のと揖，1から 7 のような照明の $\mathrm{ON} / \mathrm{OFF}$ が大部分を占め, 次 いで明るさの調光のバリエーションとして 8 のような段調光や,

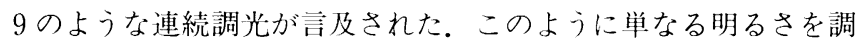
節のための言及が多く，他の目的のため，つまり先のオフィス照 明の面接実験で挙げられたような項目を挙げた被験者は殆ど見ら れず，たった一人だけが「昼光のカーテンの開け閉め」と言うよ うな昼光とのつながりを言及したに過ぎない．また被験者一人当 り 2 項目弱しか言及していない.

調節実験前後の, 調節の日常的な実施頻度と, 調節の重要度を 7 段階で評価させた結果を表17に示亦。デー夕は，それぞれ一対 の標本による平均の $t$ 検定 (片側)を行った。目常的にしていると 答えたものほど重要度の高くなる傾向にあるが，日常的にしてい る度合いは，向きをかえる調節を除いて，調節実験前重要度評価 に比べ評価が低く( $1 \%$ 又は $5 \%$ 有意), 重要視しているわりには なかなか行動は伴わないと判断できる.

調節実験前後の重要度評価を見比べると，一般的な明るさの調 節, 省工ネのための調節の重要度は実験前後であまり変わらない (それぞれポイントの上昇度は 7 点満点中 $+0.18,+0.09)$ 。一般 的な明るさの調節に関しては，実験前からその重要性を被験者が 理解していたためそれ以上評価が上がらなかったことが，また省 エネのための調節に関しては量天日の実験が多かったため无分に その重要性が充分に評価されなかった可能性がある。一方，手暗 がり等による光の向きの調節の重要性は実験中に充分経験してい るためか, 実験後には実験前より重視される $(+0.55,5 \%$ 有意)。 また䨌讲気のための調節に関しては, 実験後に経験したたことで, 評価が上がる ( $+0.55,5 \%$ 有意).

このようにオフィス照明の調節は，実際に体験することでその 重要性と意味を理解でき, 調節という項目があらたにオフィス照 明の意識へとくみこまれる。つまり，調節の機会のないところで は，その重要性に気付く可能性は低く，あらたに調節という事柄 がオフィス照明の意識の中に培われることはないであろうと推測
される。

\section{6.まとめ}

本研究では, 以下の知見を得た。

面接調査を通じ,オフィス照明の認識で重要視される項目には, 上位三項目は「明るさ」「グレア」「自然光」で各属性とも共通で あるが, 4 番目以降には属性間差異があらわれることが分かった。 また「調節」は, 重要度評価でも 14 項目中 7 位であり重要度はそ れほど高くないが，デザイナーと一般オフィスワーカーにとって は，オフィス照明を解釈し理解する上で他の項目との連結を果た す役割を果たしているため重要な検討項目であると考えられた。

面接調査で一番重要とされた「明るさ」と言う項目を，「明るい 一暗い」という軸上で写真評定させた結果, 同じ写真でも評価の ばらつきが大きく, 明るさに対する被験者間差異を考虑して満足 度の高いオフィス照明を丰現するための手段の一つとして，個人 の好みに応じて照明環境を調節することを捉える必要性が示され た。

明るさの調節の効果の量的検討のための実験を通じ, 以下のこ とが明らかになった。

perceived control は, 全般照明の照度を上げられる場合は正に 働き，夕スクライトの照度を上げられる場合は初期状態の夕スク アンビエント比が影響すると考えられ，タスクライトの照度を下 げられる場合は，タスクライトの点灯照度によりその評価のされ 方が異なり, タスクライトの照度が高い $(400 \mathrm{~lx})$ と負, 低い (200 1x）と正であった。

全般照明の照度を上げられる時は, 照度変化, behavioral control 共に評価を上げる効果があるが, タスクライトの照度を変え られる時は, 照度変化のみ与之られた場合と自分が明るさの変化 に関わった場合とで同じ光環境に対して評価が異なり, 照度変化 は照度が上がる程良いという一般的な評価がされる一方で, behavioral control は照度を上げる時は厳しく評価し, 下げる場合 は良くなった点を課題評価させる効果があると考えられた。

初期照度が同じ時(照度を上げる300 lx, 下げる $1100 \mathrm{~lx}$ ) は, 全 
般照明の照度を上げられる場合，タスクライトの照度を上げ下げ する調節は共に, 照度変化量の多い方が照度変化と behavioral controlの効果が大きいことが明らかになった. 照度の上げ幅が 同じ $2001 \mathrm{x}$ で初期照度が異なる時は, 全般照明の照度を上げられ る場合は, 調節後に得られた照度水準が, behavioral control と 照度変化の効果に大きな影響を与えると推測され, タスクライト の照度を上げる又は下げる場合は共に，照度変化は初期照度が高 い方が効果が高く, behavioral control は調節後の光環境がより 作業に適した状態になる可能性のある初期照度（本実験では低い 方）が効果が高かった.

尚, behavioral control, 照度変化の効果は有意差が殆どなく, その効果は非常に小さいことが分かった。

明るさ調節実験の前後に行った照明の調節に対してのアンケー 卜調査からは, 実験前に比べ実験後の調節に対する重要度が上が ったことから, オフィス照明の調節は, 実際に体験することでそ の重要性と意味を理解でき, 新たに調節という事柄がオフィス照 明の意識が培われると推測された。

このように, オフィス照明の明るさの調節は, 初期照度や照度 の上げ幅下げ幅でその効果が違うことと, その明るさの変化に自 分が関係しているか否かでその評価の仕方が異なることが明らか になった. 今後さらにオフィス室内照明の個別調節化の実用化を 進めるには, 様々なバリエーションに富んだ初期照度と照度変化 量を設定し, 照度変化と behavioral control の効果を明確化する とともに, 調節へのかかわり方のバリエーションとして例えば同 室他者が調節を行った場合や人感センサやタイマー式の機械など によって明るさの変化が制御されている場合などの影響について も，十分な検討が必要であろう。

本研究の一部は社団法人照明学会の奨励研究（平成10年度）の 助成を受けて行いました。ここに感謝の意を表します。

本研究の一部は社団法人照明学会平成11年度オフィス照明の質 的評価委員会の協力を得て行いました。関係各位に御礼申し上げ ます。

\section{参 考 文 献}

(1) Jennifer Veitch : Choice, perceived control and performance decrements in the physical environment, Journal of Environmental Psychology, Vol.16, pp.269-276 (1996).

(2) Corah, N. L. \& Boffa, J. : Perceived control, selfobservation, and response and cognitive processes, Journal of Personality and Social Psychology, 16, pp.1-4 (1970).

(3) Averill,J.R. : Personal control over aversive stimuli and its relationship to stress, Psychological Bulletin,Vol.80, pp.286-303 (1973).

（4）宮澤, 中村, 小林：室内照明の明るさの調節と満足度評価, 日本建築学会計系論文集, No.530，2000年 4 月.

(5) Barnes, R. D. : Perceived freedom and control in the built environment. In J. Harvey, Ed., Cognition, Social Behavior, and the Environment. Hillsdale, NJ : Erlbaum, pp.409-422 (1981)

(6) CIE Publication No.29, Guide on interior lighting
(1975).

\section{引用文 献}

（引用 1 ) "a determinant of the cognitive appraisal of threat", Corah, N. L., \& Boffa, J. Perceived control, selfobservation, and response and cognitive processes, Journal of Personality and Social Psychology, 16, pp.1-4, (1970), 4 ページ.

(引用 2 ) “direct action on environment”, Averill, J. R. : Personal control over aversive stimuli and its relationship to stress, Psychological Bulletin, Vol.80, pp.286-303 (1973), 286ページ.

(引用 3 ) “perceived control is perception that one's choices determine outcomes", Barnes, R. D., Perceived freedom and control in the built environment. In J. Harvey, Ed., Cognition, Social Behavior, and the Environment. Hillsdale, NJ : Erlbaum, pp.409-422 (1981).

(受付日 2000 年 8 月 18 日 /採録日 2001 年 5 月 31 日)

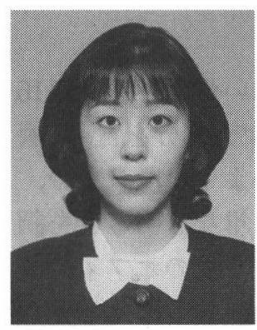

宮澤縫衣子（正会員）

Universitas Indonesia

Gudung II, Lt.1 Depok 16424 Indonesia 昭和 47 年 5 月 26 日生まれ。平成 8 年 3 月日 本女子大学家政学部住居学科卒業. 平成 10 年 3 月東京工業大学総合理工学研究科人間環境 システム専攻修士課程修了, 平成 13 年 3 月同 博士課程修了. 工学博士. 建築学会会員.

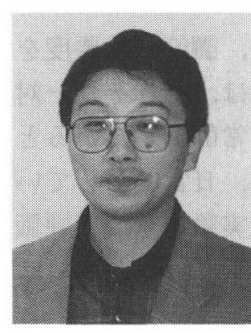

\section{中村 芳樹 (専門会員)}

東京工業大学大学院総合理工学研究科

昭和 31 年 11 月 4 日生まれ。昭和 61 年 3 月東 京工業大学大学院社会開発工学専攻修了. 同 年東京工業大学助手, 平成 5 同大学助教授. 工学博士。専門は視環境評価, 環境心理学. 日本建築学会, 日本色彩学会, 日本感性工学会, MERA 会員.

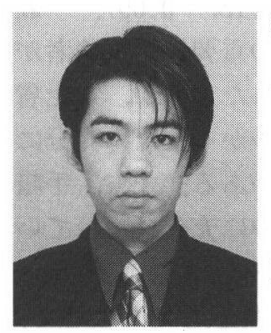

若狹 直毅（正会員）

ナショナル住宅産業株式会社

昭和 52 年 1 月 14 日生まれ。平成11年 3 月武 蔵野工業大学工学部建築学科卒業. 平成 13 年 3 月東京工業大学総合理工学研究科人間環境 システム専攻修士課程修了, 同年 4 月ナショナル住宅産業株式会 社に入社. 工学修士. 建築学会会員. 